\title{
X. Country/Region Reports
}

\section{Nordic Countries}

\section{Norway}

(1) Ratification of, and Accession to, International Agreements

On 12 May 2017, Norway ratified the Minamata Convention on Mercury, which aims to protect both the environment and human health from adverse effects of anthropogenic emissions and releases of mercury and mercury compounds (Article 1 of the Convention). Upon ratification, Norway declared the following regarding the means for dispute settlement: 'In accordance with Article 25, paragraph 2 of the Convention, Norway hereby declares (b) Submission of the dispute to the International Court of Justice'.

On 6 September 2017, Norway ratified the Kigali Amendment to the Montreal Protocol on Substances that Deplete the Ozone Layer. The Amendment sets the time frame for phasing-down the production and use of hydrofluorocarbons (HFCs). For Norway, this implies attaining a ten per cent reduction in 2019, and a gradual cut of HFCs towards reaching the eighty-five per cent reduction target in 2036. The Kigali Amendment will enter into force on 1 January 2019.

(2) Entry into force of International Agreements or Amendments

In 2017, a number of international agreements and amendments to agreements to which Norway is a party to entered into force. These encompass the following: the Agreement for cooperation between Norway and USA concerning peaceful uses of nuclear energy; the Amendment to the Agreement between Denmark, Finland, Iceland, Norway and Sweden regarding the Nordic Environment Finance Corporation (NEFCO); the Amendment to the Convention on environmental impact assessment in a transboundary context; the Agreement between Norway and Finland regarding fishing in the Tana watercourse; the Amendment of 24 May 2017 to the Agreement between Norway and Finland regarding fishing in the Tana watercourse; the Amendment to the Convention on future multilateral cooperation in the Northwest Atlantic fisheries; and the Agreement between Norway and Finland regarding 
maintenance of reindeer fences and other measures to prevent reindeer from entering the territory of the other country.

(3) Global, Regional and Bilateral Relations and Co-operation

Norway continues to actively engage in and promote co-operation on different fronts. In the context of the European Economic Area (EEA), the conclusions of the $47^{\text {th }}$ and $48^{\text {th }}$ meetings of the EEA Council indicate that Norway is committed to continue its cooperation with the EU and the other EEA EFTA States in relation to environmental, energy and climate change policies. The EEA Council placed particular emphasis on the cooperation in relation to the 2030 Framework for Climate and Energy, and the Framework Strategy for a Resilient Energy Union with a Forward-Looking Climate Change Policy. In addition, through the EEA and Norway Grants, Norway continues to fund efforts to promote blue and green growth, environmental protection and climate change mitigation. The cooperation agreements concluded in 2017 with Portugal and Latvia under the EEA and Norway Grants are cases in point.

In 2017, Norway held the presidency of the Nordic Council of Ministers. The programme for the Norwegian presidency, which laid out the foundations for intergovernmental co-operation of the Nordic States, focused on three pillars: the Nordic Region in Transition, the Nordic Region in Europe, and the Nordic Region in the World. Each of these pillars encompassed a component directed at climate and environmental issues, with the overarching goal being green transition.

Norway also continued with its contribution under the UN program on Reducing Emissions from Deforestation and Forest Degradation (REDD), granting substantial funding to a number of countries. The re-affirmation of the partnership with Peru to combat deforestation in the Amazon and the allocation of NOK 600 million to support Ethiopia's sustainable forest management and restoration until 2020 are key examples. At the same time, it is noteworthy that Norway did reduce payments to Brazil due to the increased deforestation of the Amazon. This reduction ought to encourage a strengthening in Brazil's efforts to combat deforestation.

In March, Norway hosted the first meeting of the Parties to the Agreement on cooperation on Marine Oil Pollution Preparedness and Response in the Arctic (Canada, Denmark including Greenland and the Faroe Islands, Iceland, Finland, Norway, Russia, Sweden and the USA). The purpose of the meeting was to, in light of the joint oil spill 
exercises conducted in 2014 and 2016, review the annexes to the agreement and assess whether the later required modification. The parties also discussed further cooperation plans.

In August, Norway endorsed the Under2Coalition, a pact amongst national and subnational governments aiming to attain ambitious climate change goals, namely the reduction of greenhouse gas emissions towards net-zero values, by 2050. In this context, the Norwegian Ministry of Climate and Environment signed a Declaration of Intent with the California Environmental Protection Agency, which aims to promote climate action and a transition to a low-emission economy. Under this declaration, Norway commits itself to cooperate in the development of solutions in the fields of climate change, reduced deforestation, zero emission transportation, and climate friendly energy system.

Finally, in relation to the Arctic, it is important to mention the conclusion of the negotiations on the draft Agreement to Prevent Unregulated High Seas Fisheries in the Central Arctic Ocean amongst the five Arctic coastal States (Norway, Russia, USA, Canada and Denmark), Iceland, the EU, Japan, South Korea and China. Under the agreement, the Parties commit themselves to abstain from engaging in any unregulated fishing in the high seas of the Arctic Ocean, and to collaborate in research and monitoring efforts concerning the relevant fish stocks and ecosystems. For this purpose, the draft agreement envisions creating a Joint Program of Scientific Research and Monitoring. As there is no commercial fishing in the central Arctic Ocean, this agreement is unprecedented and it strongly embodies the precautionary principle. In effect, it prohibits the parties from engaging in commercial fishing activities without a proper scientific understanding, management, and regulation of the fish stocks and ecosystems of that area. The Parties reached an agreement on the fifth and final round of the negotiations process on 30 November 2017. The agreement is now in the process of legal, technical, and translation adjustments so it is not yet open for signature.

(4) Legislative Measures of International Interest

The Norwegian Parliament adopted on 26 June 2017 a new Climate Change Act (Lov om Klimamål (Klimaloven)). The Act aims to promote the implementation of Norway's climate targets as part of a transition to a low-emission society by 2050 , and applies to the emissions covered by Norway's first nationally agreed contribution under the Paris Agreement. By this Act, Norway commits itself to reduce greenhouse gas emissions by at least forty per cent compared to 1990 levels, by 2030; and by eighty to ninety-five per cent 
compared to 1990 levels, by 2050. The Act also determines that the Norwegian government will undertake stocktakes to assess progress and submit to the Parliament updated climate targets by 2020 and every five years thereafter. In line with the Paris Agreement, each reviewed target must represent a progression beyond the previous one. In addition, the Act establishes reporting duties to the Parliament. That is, it compels the government to disclose the climate effects of the State budget, explain how it plans to achieve the targets set in the Act, and to present its climate policies to the Parliament on an annual basis. The shortcoming of the Act is that it does not establish specific and legally binding emission reduction targets. For this reason, the Act must be seen in tandem with Norway's nationally determined contributions (NDCs) under the Paris Agreement. However, it must be emphasised that while Norway's NDCs offers a clearer picture of the type of emissions and targeted sectors, the legal nature of NDCs remains uncertain. The Climate Act came into force on 1 January 2018.

(5) Policy

In 2017, the Norwegian government presented a number of white papers of relevance in the context of environmental protection, climate change, and natural resources management.

The white paper on the place of the oceans in Norway's foreign and development policy (Meld. St. 22 (2016-2017)), an extension of the government's 2017 ocean strategy, is of particular relevance. Never before had the oceans been placed within the context of Norway's foreign and development policy. It identifies the following as priority areas for Norway's external action: sustainable use and value creation, clean and healthy oceans, and blue economy in developing countries. Norway's purpose is to support the development of sustainable ocean-based industries whilst, at the same time, contributing to the promotion of global solutions to combat the environmental and climate change threats to the world's oceans. The white paper explains at length Norway's objectives and planned measures in relation to oil and gas, maritime industry, shipping, seafood industry, fisheries and aquaculture, and emerging ocean-based industries. The prevention of pollution from landbased and offshore sources, the reduction of marine litter and micro plastics, and the adoption of measures that mitigate climate change impacts on the oceans are identified as essential goals. The importance of marine protected areas and other area-base management measures as tools to promote both conservation and sustainable use of marine resources is also underlined. Finally, Norway envisions increasing cooperation with developing countries. This includes 
cooperation with small island developing states on climate change issues, and cooperation with developing countries in general for the development of their blue economy. Assistance may occur, inter alia, through cooperation programmes such as the Oil for Development Programme and the Fish for Development Programme.

The white paper on common responsibility for common future (Meld. St. 24 (20162017)) underlines that attaining the global sustainable development goals requires concerted action on multiple fronts and across multiple actors. Norway has elected five thematic areas to which it will grant priority in its development policy. One of these priority areas is that of 'climate, renewable energy and the environment'. Norway's goals are to continue to foster synergies for investments in renewable energy, for the development of measures related to mitigation of climate change and environmental degradation, and to assist other countries. Assistance to other countries encompasses cooperating with them in the development of adequate legislation, in the transfer of know-how, in the improvement of the management of energy resources, in the implementation of greater transparency, and in the provision of other assistance in relation to environmental and climate change issues.

The white paper on a greener, smarter and more innovative industry (Meld. St. 27 (2016-2017)) outlines the government's goal of achieving the best possible value creation within a framework of sustainability, and the commitment to enhance the green transition of the Norwegian economy. The paper places Norway's industrial policy within the context of an era dominated by environmental concerns and climate change challenges. It envisions the continued adaptation of Norway's industry to more stringent emission and pollution constraints, and to the need to engage in more climate and environmentally friendly production methods. Support for research, innovation, and technological development is also indicated as paramount to attain the aforementioned goals.

The white paper on Norway's fisheries agreements (Meld St. 28 (2016-2017)) provides an overview of Norway's efforts in international fisheries cooperation, fisheries agreements, state of the most important fish stocks shared with other countries, and advice on regulation of fish stocks. It also highlights the overarching goals of Norway's participation in fisheries negotiation processes before international organizations for resource management. Norway aims to ensure adequate management of living marine resources on the basis of best available scientific knowledge and ecosystem-based approach, to secure for itself fair shares in quota allocation of common fish stocks, and to ensure that there is satisfactory control and enforcement. Some points of interest in this white paper include the premises for Norway's fisheries agreements (such as compliance with international legal framework, observance of 
framework conditions for the management of marine biological diversity, and best scientific evidence/advise as basis for fisheries management), and Norway's efforts in cooperation against illegal fishing.

The white paper on the marine environment in the Norwegian Sea (Meld. St. 35 (2016-2017)) updates the 2009 management plan for the Norwegian Sea. It conveys an encompassing view of business activity in the Norwegian Sea, the potential for value creation, and of the environmental conditions therein. It depicts the environmental condition of the Norwegian Sea as good but still facing a number of challenges such as those deriving from climate change, sea acidification, maritime sedimentation, decline in seabirds, pollution from waste and micro plastic, and pollution from hydrocarbon activities. In view of these challenges, the white paper also identifies a number of measures and announces the elaboration of specific plans to ensure ecosystem-based marine management, sustainable use of marine resources, and protection of the marine environment. The white paper also reviews the different competing uses in the Norwegian Sea and discusses the need to identify particularly valuable and vulnerable areas and establish marine protected areas.

The white paper on the climate strategy for 2030 - European cooperation (Meld. St. 41 (2016-2017)) establishes the lines along which Norway will work to fulfil commitments made under the Paris Agreement in cooperation with the EU. The white paper depicts the challenges posed by climate change, identifies Norway's and EU's climate goals, examines the relevance of the EU's Climate Change Framework for Norway, explains Norway's focus on reduction of domestic emissions and use of EU's flexibility mechanisms, lays out a strategy for cooperation with the EU and EU Member States, and identifies possible measures and instruments to reduce emissions across various sectors.

The white paper on Norway's national transportation plan 2018-2029 (Meld. St. 33 (2016-2017)) underlines the goals of increasing mobility in Norway and contributing to value creation, whilst, at the same time, reducing costs with public transportation and reducing the emissions of the transport sector. In Norway, the transport sector is responsible for about sixty per cent of emissions from sectors outside the EU Emissions Trading System. This highlights the need to adopt further measures that will contribute to reduce the sector's emissions, such as establishing targets for zero-emission vehicles, implementing fuel changes, and supporting technological developments in the sector. Norway sets a target for the transport sector of thirty-five to forty per cent emissions reduction by 2030, compared to 2005 values.

(6) Case Law 
Four cases against Norway stood out during 2017 - Greenpeace Nordic Association and Nature and Youth v. Norway, Fauchald v. Norway, and two cases initiated by the World Wildlife Fund-Norway against Norway.

Greenpeace Nordic Association and Nature and Youth v. Norway has been labelled in Norway as 'the trial of the century'. The case stemmed from the Norwegian government's decision, adopted by Royal Decree of 10 June 2016, to license new blocks of the Barents Sea for the development of deep-sea oil and gas exploitation - the $23^{\text {rd }}$ licensing round. The plaintiffs (Greenpeace Nordic Association and Nature and Youth) supported by the intervener (Grandparents' Climate Campaign) filed the initial petition before the Oslo District Court in October 2016. The trial took place in November 2017 and the court rendered its judgement in January 2018. The plaintiffs' and the intervener's requested the court to declare the aforementioned Royal Decree wholly or partially invalid. Their main argument was that the government's decision was contrary to Article 112 of the Norwegian Constitution. Paragraph one of the latter provision establishes that:

'[e]very person has the right to an environment that is conductive to health and to a natural environment whose productivity and diversity are maintained. Natural resources shall be managed on the basis of comprehensive long-term considerations which will safeguard this right for future generations as well.'

According to the plaintiffs and the intervener, the first paragraph of Article 112 grants individual rights and imposes a prohibition on official decisions that involve a risk of negative effects for the environment. Such decisions are only permissible when sufficient measures are taken in accordance with the third paragraph of Article 112, which compels the authorities of the State to take the necessary measures to implement the principles of Article 112. The understanding of the plaintiffs and of the intervener is that Norway has not taken such measures. The plaintiffs and the intervener also argued that the government's decision was contrary to Section 3-3 of the Norwegian Petroleum Act, which regulates production licenses, as those provisions need to operate in tandem with Article 112 of the Constitution. In addition, the plaintiffs and the intervener argued for the inadequacy of the assessment made by the government prior to adopting the licensing decision and the necessity for government's actions to be consistent with the precautionary principle. Moreover, they also underlined the particular vulnerability of the ecosystem in the Barents Sea, the effects of black carbon on ice, 
the harsh ice and climate conditions for the operations, the potential catastrophic consequences of oil spills in that area, the limited economic value of operations in that area, and Norway's global carbon footprint. The Norwegian government fundamentally disagreed. The government's position is that Article 112 does not grant individual rights but rather sets a common fundamental value. As such, the provision does not create on its own a basis for substantive environmental rights. The State also emphasised that it had met the duty to take measures as prescribed by paragraph three of Article 112 and that no procedural errors had been committed that could invalidate the licensing decision. Moreover, given the fact that the Parliament had voted on the licensing process, the government also believed that the decision should not be subject to judicial review.

This case is another example of the growing trend of climate lawsuits. Its significance in the debate as to the contribution of Norway's hydrocarbons activities for climate change and the future of those activities cannot be understated. It also illustrates particularly well the paradox of Norway's position as a strong advocate for climate change and a hydrocarbons producing and exporting country. On 4 January 2018, Oslo District Court found in favour of the State. The plaintiffs and the intervener have appealed this decision. More information on the Court's decision and on the appeal will be included in the 2018 edition of this Yearbook.

The case of Fauchald v. Norway relates to Norway's (non)compliance of its obligations under the Convention on Access to Information, Public Participation in Decisionmaking and Access to Justice in Environmental Matters (Aarhus Convention). More specifically Norway's (non)compliance with the provisions on access to environmental information and access to justice (Article 4, paragraphs 3(c), 4, 6, and 7, and Article 9, paragraphs 1 and 4 of the Aarhus Convention). On 19 June 2017, the Compliance Committee under the Aarhus Convention rendered its conclusions on what had been a rather lengthy case. The case originated in 12 January 2011 and stemmed from Professor Fauchald's request to the Norwegian Ministry of the Environment to obtain access to a legal assessment referred to in the preparatory works of Norway's Act No. 100 of 19 June 2009 relating to the Management of Biological and Landscape Diversity (Nature Diversity Act). The Ministry of the Environment rejected this request on 19 January 2011 on the grounds that the legal assessment in question - an assessment of the relationship of the provisions of the Nature Diversity Act with international law - fell outside the definition of environmental information of the Environmental Information Act; and that the necessity to safeguard the internaldecision making procedures of the government fell within the exemptions to the Freedom of 
Information Act. Following this rejection, Professor Fauchald filed a complaint with the Parliamentary Ombudsman, which, after ten months, requested the Ministry of the Environment to reconsider its decision. The Ministry's answer to this request came eleven months later but again to no avail. After prolonged exchange of views, the Ombudsman decided on 10 June 2013 to take no further action albeit considering that the Ministry's response was still not entirely satisfactory. That final decision came two-and-a-half years after Professor Fauchald's initial information request. Professor Fauchald then appealed to the Compliance Committee under the Aarhus Convention on 26 June 2013, which rendered its conclusions four years later. Even though the Compliance Committee did not acquiesce to all of the claims raised by Professor Fauchald, it did conclude that the Parliamentary Ombudsman had failed to be 'expeditious' and 'timely' as required by Article 9 of the Aarhus Convention. The Committee did not made any recommendations as there was no evidence of a systemic error, but its conclusion clearly signalled that Norway needed to improve its procedures regarding access to environmental information.

Finally, the two cases World Wildlife Fund Norway (WWF Norway) v. Norway relate to Norway's decisions to cull wolves in Norway. On 26 June 2017, the Regional Carnivore Management Committee in regions four (Oslo/Akerhus/Østfold) and five (Hedmark) adopted two decisions establishing quotas for the culling of wolves. A number of environmental organisations appealed both decisions before the regional management authority but without success. Following this, they submitted a complaint to the Ministry of Climate and Environment, which, in a decision of 25 September 2017, dismissed the complaint regarding the first decision on culling of twelve wolves. On 2 November 2017, WWF Norway applied for a temporary injunction before the Oslo District Court to assess the validity of the Ministry's decision and requesting the suspension of the culling of the wolves. In the hearing that took place on 14 November 2017, WWF Norway underlined that wolves are a protected species in Norway, critically endangered, and on the Norwegian red list of endangered species. Moreover, WWF Norway also argued that the decision contravened the terms of Section 18 of the Nature Diversity Act. This provision allows the culling of wolves to prevent damage but only if this does not jeopardise the survival of the wolf population and if the prevention of damage cannot be achieved by other satisfactory manners. WWF Norway sustained that the decision threatened the survival of the wolf population, that a proportionality assessment had not been conducted, and that other methods had not been discussed or tried. Moreover, WWF Norway also submitted that the Ministry's decision did not correctly take into account the precautionary principle enshrined in Section 9 of the 
Nature Diversity Act or the cumulative effects and ecosystem approach enshrined in Section 10 of that Act. In addition, the decision also contradicted Article 9 of the Bern Convention on the Conservation of European Wildlife and Natural Habitats, and Article 112 of the Norwegian Constitution. The Ministry considered the requirements of Section 18 of the Nature Diversity Act to be fulfilled. It argued that the term 'population' encompassed the south Scandinavia wolf population instead of just Norway's population, and consequently the removal of twelve animals did not affect the survival of the wolf population. Moreover, the Ministry also pointed out that there are no other realistic alternatives to control wolves outside their designated areas and that they do represent a risk. The Ministry also pointed out that the Bern Convention Standing Committee has never criticised Norway's management decisions regarding wolf population. The court found that there were procedural errors and an incorrect application of the law in the assessment of whether the culling decision did threaten the survival of the population. The Court suspended the decision to cull twelve wolves. On 1 December 2017, and after addressing the errors pointed out by the court, the Ministry decided to re-authorise the culling of wolves - twelve outside wolf areas, and twenty-four inside Osdalen, Julussa and Slettås. On 13 December 2017, WWF filed another application for a temporary injunction in Oslo District Court to suspend the Ministry's decisions. The premises and arguments of the parties were essentially the same as described above but this time, the Ministry sustained that it had addressed in its decisions the concerns previously expressed by the court in the first injunction case. On 5 January 2018, the Oslo District Court did not find procedural or legal errors in the Ministry's decisions and dismissed the injunction.

Maria Madalena das Neves maria.m.neves@uit.no 